privileged Solidarity of Active Researchers, but all his brave attempts to reform The System were defeated by the strength and cunning of the Old Guard, who even went so far as to refuse money offered by the University Grants Committee for the creation of additional science professorships, lest this should lead to the appointment of more Dissidents and Enemies of the Party like Krebs. Despite these rebuffs, Krebs describes his life at Oxford as a happy and successful one. Asked once for a guiding motto, Krebs replied "Never put off till tomorrow what you can do today", which sounds like one of those recipes for virtue Victorian children were made to embroider and hang over their beds. The King of France says it less prosaically in All's Well that Ends Well:

Let's take the instant by the forward top; For we are old, and on our quick'st decrees, The inaudible and noiseless foot of time Steals ere we can effect them.

Krebs emerges from this book as a dynamic scientist and an engaging, warm-hearted individual utterly devoted to his research and teaching. He quotes Noel Coward's saying that "work is fun, there is no fun like work". I agree.

M.F. Perutz is a Member of the Medical Research Council Laboratory of Molecular Biology, Cambridge. With John Kendrew he was winner of the Nobel Prize for Chemistry in 1962.

\section{$\longrightarrow$

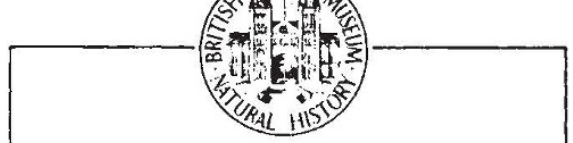 \\ AN ENUMERATION OF THE FLOWERING PLANTS OF NEPAL}

Vol.1 Gymnospermae \& Monocotyledones. H. Hara, W.T. Stearn \& L.H.J. Williams. June 1978. $£ 22.50$

Vol.2 Dicotyledones I.

H. Hara \& L.H.J. Williams.

June 1979.

$£ 22.50$

Vol.3 Dicotyledones II.

H. Hara, A.O. Chater \& L.H.J. Williams.

May 1982.

632.00

The publication of the third volume completes this joint project of the British Museum (Natural History) and the University of Tokyo. It is based on the extensive botanical exploration of Nepal by British and Japanese scientists during the last 25 years.

Publications Sales,

British Museum (Natural History), Cromwell Road, London SW7 5BD

Circle No.31 on Reader Enquiry Card.

\title{
Professors, parasites and public health
}

\section{Anthony C. Allison}

New Guinea Tapeworms and Jewish Grandmothers: Tales of Parasites and People. By Robert S. Desowitz. Pp.224. ISBN 0-393-01474-6. (W.W. Norton:1981.) $\$ 12.95, £ 8.75$.

DURING the period following the Second World War, a few pioneers of a particular type flourished. They were motivated by curiosity about medical problems in primitive societies, the people themsclves and how social organization affects health. In an era of liberal funding they were able to spend a great deal of time travelling to New Guinea, South-East Asia, the Australian outback, East and West Africa and other appealing places, collecting thousands of samples of blood, brains and other materials. For some time they were regarded as amusing, if somewhat irresponsible, amateurs, who should settle down and do serious research in Bethesda or London. But they enjoyed themselves, satisfied their curiosity and carried out research of real quality, sometimes solving problems that had for decades defied frontal attack in the United States and Western Europe.

Carleton Gajdusek transmitted kuru, a degenerative disease of the central nervous system, from cannibals of the New Guinea highlands to chimpanzees. His energy and vision played a large part in development of the concept of slow viruses. Baruch Blumberg found that certain sera of North Americans who had received blood transfusions precipitated a component in the sera of some Australian aborigines. Out of this seemingly trivial observation came the identification of hepatitis $B$ virus and the development of a test that has nearly eliminated post-transfusion hepatitis in the United States and Western Europe. Both of these developments won Nobel prizes. Following Denis Burkitt's observations on the prevalence of a particular type of lymphoma in Uganda and other East African countries, Tony Epstein identified in the lymphoma cells the herpesvirus that bears his name. This was found to transform human lymphocytes, to cause infectious mononucleosis and to be associated with a type of cancer of the nasopharynx common in parts of East Africa and China. It is the first likely candidate for a human cancer-inducing virus. The identification of the single amino-acid substitution in sickle-cell haemoglobin, and the demonstration that this gene confers resistance to malaria, were notable contributions to molecular and population genetics.

Included in this group of individualists is Bob Desowitz. After an orthodox training in tropical medicine, he worked on sleeping sickness in Nigeria and on various parasitic diseases in Singapore. He then became Professor of Tropical Medicine in Hawaii, and has travelled as a consultant for the World Health Organization and national governments to New Guinea, Indonesia, Burma and other places. This is a life that many might envy, and its highlights are recounted in this book of essays. Although the title might seem flippant, the book is instructive and entertaining.

Desowitz has a clear and readable prose stylc. Most medical students and biologists are bored by the life cycles of parasites. It helps to know that the fish tapeworm Diphyllobothrium latum was introduced into the fish of the lake region of Minnesota and Wisconsin by Scandinavian fishermen and was not killed during the delicate cooking of gefilte fish by New York grandmothers. The book is packed with easily assimilated information about parasites. Desowitz is an amusing raconteur and enjoys the detective side of public health, such as finding that a common brain infection among the Ekari of New Guinea was cysticercosis (tapeworm disease) transmitted by pigs given to the people by President Suharto of Indonesia to sweeten the military occupation.

The two central themes of the book are, first, that man-made ecologicalenvironmental changes have been responsible for perpetuating and intensifying the majority of infectious diseases; and, second, that ultimately effective control of these infections will follow widespread use of the timehonoured, sensible approach of environmental sanitation.

Each of these assertions is open to debate. It is true that building the Aswan high dam in Egypt increased the already high risk of developing schistosomiasis in Egypt, but that has to be balanced against the manifest advantages of building such a dam. Whenever such enterprises are contemplated, the environmental health implications should be considered by international experts convened by the World Health Organization and the Food and Agriculture Organization. Determined efforts should be made to prevent such health problems; this would be a useful way to use international aid funds, which are often squandered.

Does control of disease necessarily require the time-honoured, sensible approach of environmental sanitation? Nobody would argue against sanitation. But with labour and fossil fuel costs escalating, there is no realistic prospect of eliminating malaria from Africa by ditches and drains or tsetse flies by scrub clcarance. Despite 30 years of the Chinese "People's War against the Snail" and Chairman Mao's poem "Farewell to the God of Plague", schistosomiasis still exists in China.

It is more realistic to employ whatever 
weapons are at hand. Environmental sanitation should be used wherever it is feasible, and coupled with health education. Immunization too, has its place. Smallpox was eliminated by a vaccination campaign carried out with military determination, and immunization markedly reduced the incidence of poliomyelitis in industrialized countries. Chemoprophylaxis and chemotherapy are also useful. They greatly reduced the prevalence of yaws and have protected millions of people and domestic animals from parasites. As in the case of chemoprophylaxis against filariasis in
Samoa, quoted by Desowitz, knowledge of the social organization of the people helped.

The essays of Desowitz provoke these and many other thoughts. They are recommended to students of medicine, public health and biology, to administrators of international health programmes and to those who enjoy a good read about science and the world in which we live.

Tony Allison is Director of the Institute of Biological Sciences at Syntex Research, Palo Alto.

\section{The making of an archaeologist}

\section{Colin Renfrew}

Mortimer Wheeler: Adventurer in Archaeology. By Jacquetta Hawkes. Pp.416. ISBN 0-297-78056-5. (Weidenfeld \& Nicolson: 1982.) $£ 10.95$.

"TURNing out of Pall Mall, I was transfixed by the steely gaze of $\mathrm{Mr}$. Augustus John. 'Hullo, Rikki,' he said; 'still digging?'. 'Hullo, Augustus,' I replied; 'still sketching?'. With these words Sir Mortimer Wheeler (Rik to his friends) began Still Digging, his vivacious autobiography, published by Michael Joseph in 1955. Its subtitle, "Adventures in Archaeology", is recalled in that of the biography of Jacquetta Hawkes, now published six years after his death.

There is no more equivocal gift to the biographer than a really good autobiography. The freshness and energy of Still Digging make it lively reading today, and its very excellence offers Jacquetta Hawkes something of a challenge, to which she has risen conscientiously and above all sympathetically, making considerable effort to get behind the public persona and reveal the human being.

It is indeed for that persona that Wheeler is still most widely remembered. For those too young to have been viewers, it is difficult to convey the national impact of his charismatic role, back in the $1950 \mathrm{~s}$, in that remarkable television programme Animal, Vegetable, Mineral. Both Wheeler and the question master Glyn Daniel became household names - they were elected "TV Personality of the Year" in 1954 and 1955 respectively. This was haute vulgarisation, in Glyn Daniel's term, popularization at its best and with a serious purpose. It made archaeology both better known and more widely understood, laying the foundation

- The third edition of Digging up Bones by D.R. Brothwell, published by the British Museum (Natural History) and Oxford University Press, appeared earlier this year. Price in paperback is $£ 8.95$. in Britain not only for more substantial subsequent television coverage (the Buried Treasure series, and then Chronicle) but also, it could be argued, for the rapid growth over the past 20 years of archaeology as a degree subject which is numerically strong in a number of universities. As the author stresses here, Wheeler was, in his early excavating days in the 1920 s, a pioneer of what today might be called public relations. But of course it was very much more than this: Wheeler saw his discoveries in human, personal terms and he never lost the gift of catching the imagination of the non-specialist. He saw, too, that if the ultimate aim of archaeology is to inform us about the human past, it is the duty of the academic not only to research but to communicate. As he wrote in his best book, Archaeology from the Earth (Oxford University Press, 1954): "In a simple, direct sense, archaeology is a science that must be lived, must be 'seasoned with humanity'. Dead archaeology is the driest dust that blows"'.

In his later years, as Secretary of the British Academy, Wheeler made substantial contributions to the development of archaeology in Britain and indeed to the standing of the humanities in general. The British Academy, a much more recent creation than the Royal Society, has even now not quite achieved the active leadership within its own field which its elder sister has among the sciences. That the two are nonetheless at least comparable owes much to Wheeler's leadership during his tenure as Secretary from 1949 to 1968 , as Jacquetta Hawkes describes most effectively.

Undoubtedly, however, Wheeler's main claim to lasting fame rests with his work as a pioneer of archaeological field methods. His incisive and systematic approach to the problems of excavation was not entirely new - as he generously acknowledged in the preface to Archaeology from the Earth, many of the methods and principles which he used were derived "from those of the greatest of all archaeological excavators General Pitt Rivers". It was to those largely forgotten publications from the end of the last century that Wheeler turned, and with their aid developed systems of recording, with emphasis upon the interpretation and drawing of stratigraphic sections, which transformed excavation in Britain from a pastime into a discipline.

Wheeler's most personal contribution was an unfailing grasp of what he called the Tactics and Strategy of excavation. Those same qualities which produced a first-class soldier (he rose to the rank of Brigadier in the Second World War and fought at El Alamein) and highly effective administrator (Director General of the Archaeological Survey of India) made him a masterly field worker, with an unrivalled perception of the real objectives of the work in hand and of the most appropriate measures for their achievement. Indeed, it could be argued that with Wheeler excavation became to archaeology what experiment is to the physical sciences - the opportunity through clear thinking and careful planning to try out new ideas and to test old ones. Of course British archaeology overseas had other pioneers of field method besides Wheeler - Sir Flinders Petrie, as Wheeler himself acknowledged, or Sir Leonard Woolley or Sir Max Mallowan. But Wheeler was the unflagging advocate of sound field method as the essential basis of further work, and his teaching in the years after the First World War promoted in Britain an awareness of stratigraphic principles which persists today and is ultimately sounder and more productive than the metrical thoroughness of the German school or the statistical enthusiasm of the American.

Jacquetta Hawkes does not perhaps evaluate as highly as she might this particular achievement, although she describes Wheeler's individual excavations fully and well. It deserves to be set in a wider context. For it would be quite possible to see Wheeler's keen sense of problem in fieldwork as anticipating in some respects the deliberately problem-orientated approaches of the "New Archaeology", which grew up in the last decade of Wheeler's life. It is not the inclination of either approach to set great store on facts just for their own sake. Both see the aim of fieldwork as the verification or testing of hypotheses through the gathering of fresh material, and recognize that it is ideas and problems which should determine the excavation strategy. This clear sense of priorities makes Archaeology from the Earth an inspiring introduction to fieldwork; still the best introduction, in my view, although many new techniques have been introduced over the past 30 years. And while the author rightly stresses Wheeler's ability to imagine and bring to life the people behind the archaeological record, his encouragement of the technical specialisms of archaeological science whether conservation or radiocarbon 